\title{
Analysis of Development Prospects of Small Innovative Enterprises System in Russia
}

\author{
Panasyuk M.V. \\ Kazan Federal University, Institute of Management, Economics and Finance, Kazan, 420008, Russia
}

Email:mp3719@yandex.ruu

Bagautdinova N.G.

Kazan Federal University, Institute of Management, Economics and Finance, Kazan, 420008, Russia

Yangirova Y.E.

Kazan Federal University, Institute of Management, Economics and Finance, Kazan, 420008, Russia

\section{Doi:10.5901/mjss.2014.v5n28p27}

\section{Abstracts}

Development of small innovative enterprises (SIE) in Russia is an actual and important way of ensuring the sustainable growth of the national economy. Analysis of foreign experience of innovative institutions development, carried out in this paper, helps to construct the system of small innovative enterprises in Russia. It was outlined in the paper that main directions of SIEs development will be linked mainly with scientific researches and short-scale production. Prospects of Russian small innovative enterprises are discussed.

Keywords: small business, small innovative enterprises, innovative business prospects

\section{Introduction}

Russia is acting as a supplier of not only raw materials, but also of knowledge, intellectual resources, and not of advanced technology. The reverse situation is observed in the development and adoption of advanced technologies. The increase in business demand for innovative products is resolved into extension the import of foreign high-tech innovation. To maintain and enhance Russia's positions in the knowledge production it is necessary to change scientific research policy as well as to realize the modernization of the national industrial base. Thus, there is a clear need to stimulate investments in the development of innovative technologies for national enterprises.

Otherwise, the capitalization of development and research will take place abroad, importing in Russia by competitive goods. Venture capital will not be invested in Russia in terms of depreciation of plant, and in addition a crucial role would be played by long-term return on investment in innovation sphere.

Modernization of the Russian economy creates the conditions for sustained long-term economic growth. One of the components of the innovative development of the economy will be the innovation business, and small innovative enterprises (SIE) at country universities as its necessary attribute. Establishment and functioning of SIEs at universities is based on the Federal Law \# 217-FZ "On Amendments to Certain Legislative Acts of the Russian Federation on the Establishment of Budget Scientific and Educational Institutions' Business Entities for the Purposes of Practical Application (Implementation) of Intellectual Activities" enacted in August 2009 [9].

\section{The Analysis of Foreign Experience of Developing the Innovative Institutions}

The creation and functioning of small innovative enterprises for the Russian Federation is a new phenomenon, while in developed countries these institutions began their successful work from the middle of the last century. The experience of developed countries shows extreme efficiency of national SIPs systems.

Sweden realizes the fairly loyal model for building cooperation between universities and business. There are various forms of cooperation between business and university in this country: the creation of specialized departments dealing with counseling on economic, legal and marketing issues; creating units that are responsible for the commercialization of research results; creation of holdings with rights of ownership and disposition of shares of 
companies with a view to distribution the commercial results of research activity; establishment of special centers of technology transfer that are designed to help wishing competently write a business plan, assess financial position of the enterprise, elaborate economically rationale for the innovative project; creation of centres of expertise, acting as a link between several research groups, the purpose of which is transformation of new knowledge and skills in innovative products and new services.

In Sweden, there are more than 14 holdings at higher educational institutions and more than 1,000 different kinds of cooperation. According to the report "Global Innovation Index - 2013" presented by United Nations Economic and Social Council in 2013, Sweden was leading in terms of innovation. The USA at a given index occupies the fifth position.

Functioning of the American small innovative enterprises consists of three stages: the first stage is fundamental scientific knowledge developed in high school, the next stage - national laboratories of educational institutions, the latter commercialization of scientific achievements. It is in the higher educational institutions where innovations are created and developed. For example, $3 / 4$ of discoveries, scientific achievements in the US in recent years were achieved in small innovative enterprises at universities. Establishing SIE was introduced in business practice by authors of scientific inventions, and they eventually became not only developers, but also businessmen by deploying their own scientific results [1].

Higher education institutions in Germany become initiators of creating small businesses and create support centers. In Germany, there are four major organizations involved in research - the Helmholtz Society, the Fraunhofer Society, the Leibniz Society, and the Max Planck Society. These societies have affiliated institutions that support research projects by consulting on economic and legal aspects, by preparation of business plans, financing, and deploying results of innovative projects. Start-up companies, developing innovative technologies, currently providing support and advice to more than 300 technology centers. Basically, financial support is necessary to develop technologies in medical, nuclear, biotechnology, laser, information-communication areas. In Germany there is the HTGF fund (The High-Tech Gründerfonds) which invests up to $€ 1$ million in promising scientific development [8].

For the developed economies at the end of the XX century it became obvious that economic growth and overcoming stagnation in the economy is impossible without an increase in research intensity and formation of high-tech manufacturing. These tasks were set before the newly created technology parks, which were to identify and define the vector of development of knowledge-intensive industries to conquer the promising markets of high technology products. The symbiosis of higher education institutions and businesses in each country is called quite differently: the Science Park, the Technology Park, the Technological Cluster, but have common features that are characteristic to this type of cooperation.

Pioneer of technology parks as the development facilities of innovative activity became the United States in 1951. Stanford University began to lease out land and office premises to companies operating in the field of innovation, which was actively developing due to the orders of the Federal Government in the field of military industry. This kind of cooperation gave advantages for both sides: innovative firms enjoyed relatively low rents, and the university got a real opportunity for practice and future employment of students, as well as training of workers of producing companies [2].

State support, closely collaboration with the university aimed to develop venture funding as a new financing scheme of innovative projects have become mainland for success at Stanford University. It took 30 years for full development, building infrastructure and complete construction of the technology park. The results of technology park became phenomenal achievements in the development of high technology industry sector.

In 50-ies of XX century in the United States was established 12 industrial parks, and to the 1980s innovation activity gradually began to grow, embracing new universities and states. At the moment, the number of technology clusters with functioning small innovative enterprises in the United States is more than 160 , which is $30 \%$ of the number of technology parks in the world. Some parks are transformed into business incubators to support small businesses that are at an early stage of development of high technology, getting favorable terms of taxation, low rent, legal and financial consulting.

The first European parks appeared in 70s of the XX century, which was preceded by the successful results of technology parks in the USA. One of the first was the University Research Park Sophia Antipolis in Nice. In Germany, Cologne Technology Park appeared. In the UK, the first science park was organized in 1972 in Scotland at Heriot-Watt University. In the early days of the first European industrial parks the American model of their creation were used: one founder and main business is renting land and equipment for companies engaged in innovative designs. A characteristic feature of European technology parks is becoming short period of foundation, as there was the American experience in creating business plans and elaborated programs, making the European development in this direction faster and more successful [3].

The first place for the construction of technology parks in Europe belongs to Belgium and France. The Science 
Park Leuven la Neuve, Belgium is made as the scientific city, including the socio-cultural centers, residential areas and the university. In Nice technology park was established in 1972. In Sophia Antipolis there are research centers, high school institutions, international organizations, innovation centers [6]. Creation of technology parks by the universities is typical for Netherlands, active innovation activities of science parks is widely supported by the Government of the country.

Thus, in the 50-70 years of XX century the foundation of the first industrial parks in the US and Western Europe was created. This stage is characterized by weak public support and limited innovation development. However, results of the technology parks began to have a strong impact on national economies, contributing to the restructuring, active collaboration of industry and science, to markets renovating by high technology products and, consequently, to increase in economic growth.

For Japan, the creation of these innovative structures was entirely the prerogative of the state policy. Three main purposes in the elaborated program was pursued - to promote the development of new and high-tech industries, create jobs, encourage continuous research development. A specific features of research centers in Japan was banning commercialization of intellectual property and the development of basic research in which the private organization plays almost no role.

In the 90 years of XX century innovation centers and technology parks have spread beyond the developed countries in Brazil, Singapore, Australia, India, China and Japan. For China, in 1988 one of the main directions of economic development has become strong focusing on the development of high-tech products in the fields of genetic engineering, biotechnology, and microelectronics. The result of this trend has been the development of the "Torch" national program. Currently, China has more than 120 centers for innovation development and economic revenues account for more than $\$ 4$ billion annually. The Government of China promotes high-tech start-up financing of innovative projects, and also provides tax breaks and insures risks of foreign investors.

\section{The Development of Innovation Sphere in Russia}

The first wave of technology parks in Russia was formed in early 1990s, and the main part of these institutions was organized at higher education organizations. Creating more often as a division of the university, these research centers was difficult to be called innovative. At the initial stage there was no infrastructure, no development plan, nor trained managers, so the initial centers could be called only on the application on innovation development. Legal successor of the USSR State Committee for the creation and development of technology parks in the 1990s became the Ministry of Education. For the Russian Federation, the key directions in the development of this area were: learning and adapting the foreign experience of creating technology parks, training of professionals to work in small innovative enterprises and technology parks.

The first research center - "Tomsk Science and Technology Park" was created in Russia in 1990, thanks to the "Technopark". Association In Tomsk the Technology park fully owned by the state and was opened thanks to the Tomsk regional authorities and the Ministry of Higher Education of Russia. In 1995, after the reorganization in the open joint stock company 145 scientists, industrialists and entrepreneurs were able to perform as founders. Technology park participated in changings of the urban and regional infrastructures, searching for innovative projects, commercialization of research activities, the organization of small innovative enterprises (more than 200 companies), the financing of high-tech projects.

In the nearest future, there was quantitative development in geometric progression of technology parks all over Russia: in 1990 - 2, in 1991 - 8, 1992 - 24, 1993 - 43. A feature of Russian technology parks and small innovative enterprises is remaining heavily dependence on founders in choosing not only the clients but also vectors of scientific work, complexity of the legislative framework that does not provide full development of small businesses. Organizations engaged in scientific activities for a certain reasons often remain mediocre university faculty or laboratory in plant. In contrast, the Western model of research centers development suggests considerable freedom in choice of studies, and the basic criterion of effectiveness is not quantitative indicators of established technology parks, but economic profitability of the organization.

\section{Prospects of Russian Small Innovative Enterprises}

Small innovative enterprise is an independent organization that is engaged in development and commercialization of intellectual labor of budget organizations, mostly higher education institutions. The main cause of regulating laws was the need for the commercialization of scientific research institutions in higher education, that before this law was contrary to existed principle of prohibition of commercial activities to universities. Accordingly, small innovative enterprises at 
universities is intended to engage in commercial activities.

SIEs exist in the form of a limited liability company. To become small innovative enterprises, a company must have the share of the higher education institution in nominal capital of organization at least of one third, i.e. $34 \%$. However, higher education institution is investing in the nominal capital not funding resources but patents. That is, the results of innovative activities are recorded as intangible assets.

Main participants of small innovative enterprises are the authors of scientific research, engineers, scientists, inventors who want to push their idea and commercialize theirs scientific research results. Accordingly, one part supports the idea of researcher, the other - a higher education institution.

The presence of small innovative enterprise for higher education in Russia at this point in time has only high-status nature. Number of small innovative enterprises raises rating and increases activity status of a higher education institution. At this point of time profitability of small innovative enterprises as qualitative indicator of these enterprises is not considered and neglected. In Russia, the economic benefit of small innovative enterprises at high school institutions remains low, while foreign SIPs significantly contribute to financial support of higher education institutions $[4,7]$.

However, the experience of innovation policy in developed countries show a promising sector of small innovative enterprises, which are able to provide a significant increase in efficiency of the national and regional economy. The main factors shaping the SIEs system are: the increase of the role of scientific research and fundamental theoretical knowledge; the increase in scientific services sector; increasing the share of education funding; prevalence of high-tech goods produced in small innovative enterprises.

Currently, forming innovative institutions in the Russian Federation - technology parks, special economic zones, research universities, etc. is not accompanied by the development of a unified approach to the creation of the innovation system, and solving the problem of interaction between business, science and education. Strategy of innovative development of the country must be created and developed by the state for all participants in this process [10, 11] and, first of all, for development of small innovative enterprises at universities as subject for accumulation of national intellectual resources $[5,12]$. If big enterprises would generate innovations they would use likely tested high quality foreign production, so this activity can hardly be called innovative. Also significant attention in innovation regulation should be paid to coordination of demand and supply of innovative technologies.

The state is engaged primarily in providing growth of proposals on innovation, and paying not enough attention for the formation of innovation demand. In the today's markets there is a mismatch of innovation supply and demand. Innovative proposals are in unclaimed areas, and demand for innovation in the areas which are underdeveloped in the country is not satisfied.

Considerable attention in the Russian Federal and regional programs of development of innovative activity should be directed at improving the coordination of market demand and supply on innovative technologies. While there are no explicit incentives for increasing demand for innovation outcomes, and identified potential users of the innovation are not detected it is difficult to define promising areas of small business development and to identify its innovation potential.

Stimulating demand for innovative development could be realized by changes in the external business environment on the basis of more stringent requirements for control of environmental release and energy efficiency programs. These methods are able to stimulate only a slight increase of innovative activity, which may not provide long-term stable economic growth. The situation is complicated by the presence of a significant number of companies-monopolists in Russia, which do not put high competitiveness at the forefront and therefore do not stimulate innovation.

The need for innovation can occur only if improvement the competition mechanisms in each sector of the Russian economy would be realized. In the last decade, competition in the Russian markets has increased significantly, government measures restrict activities of the monopolies creating conditions for advanced competition, which is the main precondition for the growth of innovative potential of the country, and transition to the innovative nature of the economy with intensification of small innovative enterprises.

\section{Conclusions}

Accelerated system development of small innovative enterprises in Russia is an actual and important way of ensuring the sustainable growth of the national economy, allowing to solve problems of modernization and the growth of competitiveness of goods and services on the domestic and foreign markets. Small innovative enterprises, producing twice more innovations per employee than large firms, are in the early stages of theirs development, elaborating and mastering novation, having often revolutionary perspective, seem to be unprofitable and unpromising and risky for big firms.

Analysis of small innovative enterprises shows mainly specialized scientific direction of their researches and short- 
scale production. More than half of the SIEs specialize in design of new equipment, following is software development, followed by development of nanotechnology and new materials. Small innovative enterprises will play an increasingly important role in scientific and technical progress of the country, improving quality and competitiveness of its products.

\section{References}

Haltiwanger, John C., Ron S. Jarmin, Javier Miranda (2010), "Who Creates Jobs? Small vs. Large vs. Young ", NBER Working Paper No. 16300, August 2010. See http://www.nber.org/papers/w16300.pdf?new_window=1.

Doms, Mark E., Ron S. Jarmin, and Shawn D. Klimek (2004), "Information technology investment and firm performance in US retail trade." Economics of Innovation and New Technology, 13 (7), 595-603.

National Research Council, "Rising to the Challenge: US Innovation Policy for the Global Economy", The National Academies Press, Washington, DC, 2012 See www.nap.edu

Nesterenko Y.N. (2007) Development of small business innovation - the potential formation of a knowledge economy, Russian Entrepreneurship,10(1), 25-30. - http://www.creativeconomy.ru/articles/8468/

Golichenko O. (2004) Russian innovation system: the model and its development prospects, M .: Publishing House of People's Friendship University, 2004, 286pp.

The activities of the European Union for small and medium-sized enterprises (SMEs), Luxembourg: Office for Official Publications of the European Communities, 2005.

Bortnyk I.M. (2004) 10 years of development of small innovative enterprises in Russia, Innovations, 1 (68).

Germany is not only high technology, Expert-online See http://expert.ru/siberia/2010/24/germaniyal (date accessed: 11/09/2014).

Garnier A.P., Krasnobaeva O.V. (2011) Small innovative companies as a form of implementation of innovation universities, Innovations, 3(74). See http://innovation.gov.ru/sites/default/files/documents/2014/25373/3971.pdf

The Federal Law of August 2, 2009 \# 217 - FZ "On Amendments to Certain Legislative Acts of the Russian Federation on the establishment of budget scientific and educational institutions, business entities for the practical application (implementation) of the results of intellectual activity "Innovation Strategy to 2020, M .: Development of Russia, 2010.

Regulation on the Federal Agency for Science and Innovation (in red. RF Government Decree of 13.10.2008 No 753 from 07.11.2008 by No 814 of 27.01.2009 No 43 of 14.02.2009 No134).

Razumovskaya, E.M.,Mishakin, T.S., Popov, M.L., Kucevol, N.G. Medical services during the XXVII world summer universiade 2013 in Kazan. Mediterranean Journal of Social Sciences vol. 5 (18 SPEC. ISSUE), pp. 17-20.

Arustamyan, G.,Yegorov, E., Lipsky, S.,Razumovskaya, E.,Gimranova, L. Clinical and economic analysis and its role in healthcare quality management. World Applied Sciences Journal vol. 27 (3), pp. 318-323.

Shaidullin R.N., Safiullin L.N., Gafurov I.R., Safiullin N.Z.. Blended learning: leading modern educational technologies. Procedia - Social and Behavioral Sciences. Vol. 131, pp. 105-110. // 3rd World conference on educational technology researches Turkey 0709.11.2013. 